\title{
The Consequence of Human Resource Planning on Organizational Performance: An Ephemeral Review
}

\author{
Hassan Elsan Mansaray \\ Lecturer - Department of Business Administration and Entrepreneurship Development, Institute of \\ Public Administration and Management (IPAM) University of Sierra Leone, Freetown, Sierra Leone \\ Email: hassanelsan@gmail.com
}

\begin{abstract}
:
The drive for human resource planning in every single organization is to necessitate perfect use of human resource currently employed as well as, making provision for the future human resource needs regarding skills, quantities and ages. The purpose of this review is to ascertain the practices of $H R P$ that can increase organizational performance. Consequently, the review discovered that HR planning ensures that organizations at all times have the right number of people, with the correct level of skills to do the right activities at the right time for the achievement of organizational objectives. Besides, human resource planning determines the right numerical strength of individuals that own these skills that are needed by organisations to meet the present and future business requirements. Based on this reality, organisations nowadays need to have employees that possess the right skills that could be place in the right places and at the right time they would be needed in organizations. In order to fulfill this condition, the study found out that HR planning ought to be part of any organization's objective. Incredibly, many organizations have the tendency of overlooking the side of HR planning and more or less, organizations are even not totally conscious of it. Hence, it is essential to recognize that because of the high knowledge requirements in the global market, most organizations are determine to stimulate performance, which can engender surplus profit through the application of HRP philosophy.

Keywords :

Human Resource Planning (HRP); Manpower Planning; Human Resource; Management (HRM); organizational performance.
\end{abstract}

\section{Introduction}

Organizations these days are strategising to have competitive gain over their competitors in the existing global market. Owing to the high knowledge requirements, most organizations are determine to engender the performance that can generate additional profit. In order to achieve such goal, employees need to perform well as well as improve their talent, (Al-Qudah et al 2014). In view of that, it is important for organizations to determine how many people they need and what category of people they ought to have in order to meet their present and future business needs. When, an organization assumes this role it means it is performing the task of human resource planning or workforce planning as it is called, in the public sector precisely (Armstrong 2009). As pointed out by Lunenburg, (2012) that organizations are designed by people and those related people are the most vital resource in the organization. Therefore, there is no organization that can realize its objectives without people. Likewise, there must be a suitable deployment of human resource in organizations in order to attain high-performance standard. As all organizations' objectives are achieved through actual human resource planning. In this case, effective human resource planning should be an instrument for constructing long-term planning in order to meet the workforce challenges (Choudhury, 2007). Accordingly, human resource management has the prospect to empower organizations to continue to survive in the existing competition and make profit (Werner, Jackson \& Schuler, 2012). 
What is today commonly known as human resource planning was formally called manpower planning in the late 1970s. The practice of manpower planning was fitting during the period of personnel management. Nevertheless, in the early 1980s, the term human resource planning took the place of manpower planning and was accepted in the human resource management practices because of the way it view human resource as valuable assets (Akhigbe 2013). As, Ayer \& Reeves, (1995), Wright \& McMahan, (2011) stated that organizations need to know their requirement in terms of human resource so as to meet their present and future business necessities in line with the competition in the market. According to them, this is where HR planning comes into play in deciding the right number of individuals that have the right skills, and placed in the right places at the right time they are needed in the organization. Similarly Parker and Caine (1996) buttress the importance for organizations to have the right number of manpower in order to circumvent the unwelcomed situation such as the issue of scarcity and surplus manpower.

Moreover, HR planning should be part of any organization since, it guarantees the organization to be successful in accomplishing all its objectives. Importantly, an organization's achievement lies to a large extent on its employees' skill, creativity and commitment. Amazingly, a lot of organizations have the tendency of overlooking the aspect of HR planning and some organizations are even not wholly aware of it. However, organizations that usually overlook the side of planning, have few chances to survive in the future; needless to say that a proper HR planning can help in dealing with several issues in a real way (Majumder, 2014). Based on this believe, the aspect of human resource planning was embraced by organizations. In the past, there was no proper method of managing people within organizations, even though top managers were following the human resource management practices. However, they quickly observed that proficiency on work has increased and surely there is need to develop some methods and practices that can proliferate the organizational performance. Thus, bit by bit the entire design of human resource management was prepared, which is about the staffing needs and, its demand and supply (Afzal et al (2013).

According to Mills (2013)) and Ulferts et al (2009), Human resource planning includes forecasting the organization's future human resource needs as well as planning to meet those needs. They further pointed out that human resource planning does not only requires the establishment of objectives, but also the development and implementation of certain programs such as: staffing, appraising, compensating, and training that will ensure that people are available with the appropriate characteristics and skills when and where the organization needs them. Human resource planning also consist of developing and implementing programs to improve employee performance or to increase employee satisfaction and involvement in order to boost organizational performance, along with quality, and innovation. Therefore, genuine human resource planning is a tool which is going to build an enduring aptitude that will meet those workforce challenges (Choudhury, 2007). Santos et al (2009) made mentioned that the reason for HRP is to predict the organizational needs for employees, taking into consideration the inside and outside supply of labour to meet staffing necessities. That is, to identify the gap between what is needed and what is available. Bello et al (2017) concluded that HRP do not only sort out employees' supply and demand requirements, but as well aids as a staid element of an organization's 'integrated strategy'.

Aslam et al (2013) further observed that Human resource planning is usually describe as the way of pinpointing the amount of employees an establishment needs 'in terms of high quality and quantity, hence it is seen as an ongoing process of regular and structured planning'. They further mentioned that the foremost resolution for human resource planning is to be certain that employees have the finest and close relations with their jobs. Moreover, the HR planning 
progression endorses that employees are in right quantity as necessary that is; there should be no excess or scarcity of manpower. They further stated three central purposes of human resource planning, which comprise of: 'i) labor forecast, ii) managing demand for employees and available supply in market and iii) keep a balance between labor supply and demand predictions'.

As, human resource planning comprises the prediction of what human resource the organization might need now as well as in the future and how to plan in order to meet those needs. The purpose of planning is to improve organizational performance. Thus, according to Walker (2012) performance is to achieve a convinced flawless 'tasks or objectives'. Moreover, Walker looked at performance as a connection of shared 'effort and abilities'. Therefore, industrious individuals with required skills, knowledge are probably to triumph much on their jobs. He further maintained that if, performance is a function of effort and competence, and then human resource managers should therefore recruit employees with the right skills and knowledge and; placed them in their right positions. In addition, Campbell (1999) has as well, describes performance as the 'behavior or action appropriate to the achievement of an organization's goals that can be scaled, that is, measured'. Cania (2014) resolved that: Job performance is 'what one is paid to do, or what one should be paid to do'.

Besides, researchers typically use performance to mention the array of dimensions of transactional efficiency and input and output efficiency (Stannack, 1996). Daft (2000) expressed that performance is similar to efficiency and effectiveness for a precise program or activity. Draft furthermore mentions that organizational performance is an effective and efficient way for organization's activity to attain objectives through the use of resources. In addition, efficiency in production can be measured by the following factors; 'i) increase in the size of the production ii) lesser time in the production of a unit of output iii) lesser wastage in resources including defective output iv) the use of same or less factor inputs per more output than before'. This proficiency in production can only be achieved through effective HR planning.

\section{Review of Related Literature}

Planning makes available a path, decreases doubt and reduces waste. There is no activity can be properly done without planning. Human resource planning has to do with the decisive human resource requirements, selection and socialization. Human resource planning is also called manpower planning, employment plans, and personnel plan (Bello et al). As pointed out by Terry and Michael (2010), human resource planning contains the approximation of how many qualified people are needed to carry out the apportioned activities, and whatsoever, must be done to make sure that personnel supply matches personnel demand at the suitable point yet to come. Besides, Stainer, (2012) describes Human resource planning as a tactic for the 'acquisition, utilization, improvement, and preservation of an enterprise's human resources. It relates to establishing job specifications or the quantitative requirement of jobs determining the number of personnel required and developing source of manpower'.

\subsection{Objectives of Human Resource Planning}

According to Ubeku, 1983:63) the objectives of human resource planning in all organization are to make sure the best use of human resources presently employed and to also provide the future human resources need as regards to skills, numbers and ages. This involves making sure that the organization at all times has the appropriate number of personnel, with the right skills doing the right jobs at specific times in order to achieve the organizational objectives. Nevertheless, the dominant objective of human resource planning in organization is to create a strategy of human resources development in line with the organization's extensive aims of 
economic development. Decenzo \& Robbins, (2019) emphasized that human resource planning involves putting the right number of people along with the right kind of people at the right place, the right time, as well as doing the right things that are on the same wave length for the achievement of the organizational goals. To achieve the goals of the organisation the following process should be exploited: I. to examine the current manpower portfolio. II. to Make future manpower predictions. III. Also to develop employment programmes as well as, IV. designing training programmes. It can also, embrace analysis on supply, demand, surplus, shortages and utilization of human resources. HRP concepts are also concerned with the development of serious human competence skills and attitude needed for the development of an organization steered by the corporate policies and objectives.

In addition, Santos et al (2009) and Armstrong (2009) pointed out that the aim of HRP is to estimate organizational desires for employees, taking note of the internal and external supply of labour in order to meet the staffing requirements. That is, to make sure that organization has the number of people with the right skills needed to meet forecast needs. Bello et al (2017) further stated that HRP is not only to address employee supply-demand desires, but, it is as well a serious factor of an organization's incorporated strategy. As it includes getting together data that can be utilized to appraise the usefulness of the current programs and update planners when reviews in their forecasts and programmes are required. Philosophies of human resource planning are of primary standing 'as we move through the 21 st century where a globalized workforce is the basis of competition'. Therefore, the triumph of a business or an organization is unswervingly connected to the performance of those who work for that business. Under triumph can be as a consequence of workplace failure since; hiring the incorrect people or failing to anticipate a rise and fall in hiring needs can be costly. It is therefore, important to put conscious efforts into human resource planning (Biles \& Holmberg, 2010).

In addition, Walker (1990) earlier on mentioned that the usefulness of HR planning rest on the viewpoint within which it is applied just like most organizational practices. Therefore, HR planners need to have clear and precise objectives in mind in order to better execute HR planning processes. By the same token, Ulrich (1987) stated that HR planning is accepted as a basis for the development of organizational functions that is based on missions and objectives of the business. With the support of planning, areas that need improved functioning are identified in order to make those areas develop and be successful. In this regard, lots of HR planning approaches have been advanced and organizations have also fashioned their own methodologies that are similar to those defined 'in the literature like: setting up formal objectives, identifying appropriate organizational strategies and searching for any innovative HR applications'. Consequently, organisations should take cognizance when developing their own HRP objectives. That is, they should tailor their objectives based on what is to be achieved with regard to organizational objectives so as to meet the specific requirements regarding the quantity and quality of employees they may need now and in the future (Chan \& Burgess, 2010). For instance, the most important transformation in organisation's business directions may require another shift in the nature of work performed and in employment arrangements'. In the same way, the tactical choices of an organisation will be looked at to walk around ways 'to fill an open position either from its current human resources or from those available in the external labour market' (Miner \& Crane, 1995).

In line with the above perspectives, Reilly (1999) concluded that there are a number of causes why organizations may decide to engross in some forms of human resource planning. The following are the three reasons based on a research conducted by the Institute for Employment Studies: 
1. Planning for substantive reasons, that is, to have a practical effect by optimizing the use of resources and/or making them more flexible, acquiring and nurturing skills that take time to develop, identifying potential problems and minimizing the chances of making a bad decision.

2. Planning because of the process benefits, which involves understanding the present in order to confront the future, challenging assumptions and liberating thinking, making explicit decisions that can later be challenged, standing back and providing an overview and ensuring that longterm thinking is not driven out by short-term focus.

3. Planning for organizational reasons, which involves communicating plans so as to obtain support/adherence to them, linking HR plans to business plans so as to influence them, (re)gaining corporate control over operating units, and coordinating and integrating organizational decision making and actions.

By and large, human resource planning according to Cole (2002 cited in Akhigbe 2013:390) is the concept of 'having the right number and kinds of people, at the right places, at the right times'. HR Planning will be taken to mean any rational and planned approach for ensuring:

- The recruitment of sufficient and suitable staff.

- Their retention in the organization

- The optimum utilization of staff

- The improvement of staff performance. Job design that lead to the development of various working patterns is to enhance staff performance, such as concepts like Flexible working hours (flexitime i.e. flexibility of time), Work Sharing/job sharing, Home work (doing organization work at home), Telecommuting, reduced working hours, reshaping of work, changing work life (improving the quality-of -work-life), Compressed Workweek/Compressed hours, Annual hours contracts, Zero hours contracts, Shorter workweek, Dejobbing, Job Engineering, Job Reassignment, Self-Managing Work Team (Autonomous Work Group), High Performance Work Design, Cross training, career management, individual career planning, career and retirement.

- The disengagement of staff, as necessary.

Consequently, Akhigbe (2013) has observed four types of staff that are significant in human resource planning such as, 'existing staff, new recruits, potential staff and leavers'.

\subsection{The importance of human resource planning in organizations}

HRP plays a very important role in understanding the organization's goals such as 'having the right talent with the right skills, at the right time and for the right cost'. The significance of HRP depend on its prospective to pinpoint organizational needs for skills and competencies for present and future programs equally (Randhawa, 2007). Another important aspect of HRP is that it can use a number of approaches to resolve current and expected workforce needs such as demographic analysis and retirement forecasts (Meisinger, 2007). More importantly, organisations should need HRP in order to have the right systems in place that will make sure the organization has the right jobs ready and acquires the right people for them (Al Wahshi 2016). Aslam et al (2013) highlighted, the importance of human resource planning practice by pointing out that objectives of the organization can only be reached when planning is done appropriately. As a result, organizations at foremost collect data relating to their goals and objectives, then positions people, resources as well as other skills required to meet the objectives.

Nyamupachari (n.d) piloted a research which he outline the importance of human resource planning as follows:

- Planning is not easy as one may contemplate since, it needs concentrated exertion to emerge with a programme that can ease your work. To start is difficult, but as soon as you have started there is possibility to finish and have a smiling face because everything went easily. 
- Planning starts somewhere and finished for a purpose. It includes mobilizing information that would support managers and supervisors make thorough decisions.

- Therefore, HR Planning includes getting together information, setting objectives, and making decisions that will allow the organization to succeed by meeting its objectives.

Besides, Majumder (2014) also expressed the importance of HRP as a process that has to start from somewhere and concluded for a specific purpose. It consist of assembling facts that can make sure that managers are capable to create thorough judgements. Moreover, the attained information can now be used to reach the organization's goals. She further stated that If, HR planning is realistic it may well support in responding to the four significant interrogations:

- What is the strength of the organization?

- As far as skill sets are required, what kind of employees does the organization have?

- How should the organization function in order to be able to utilize all its resources properly?

- How can the company retain its employees?

Besides, effective HR planning assists the organization to work efficiently in order to achieve success in the present times. Also, HR professionals that formulate HR planning for organizations, are doing so in order to assist the organizations to manage their staff strategically. Aside, HR planning can likewise safeguard an appropriate career planning for employees that will help them to reach their objectives. It can as well assure job mobility and in due course make the organization to be a healthier place to work (Majumder 2014).

Moreover, Armstrong A. (1992) suggested that the significance in the increase on 'productivity is one of the most critical goals in business and Human resource planning, as it is essential for the achievement and attainment of the said productivity'.

\subsection{Methods of Human Resource Planning}

As pointed out by Akhigbe (2013) that human resource planning method commences with 'requirement forecast and availability forecast'. Akhigbe explained the requirement forecast as a guesstimate of the figures and types of employees the organization desires at future dates in order to meet its goals. Forecasting requirements are make available to managers with the means of guesstimating 'how many and what types of employees will be required'. Equally, availability forecast is the assessed numbers and categories of employees the organization will have in the future. The availability forecast is a method of estimating 'incomings and outgoings' throughout the calculated period. He further explicated that the demand and supply forecasts can be examined to decide whether there are any shortfalls or excesses. In addition, Akhigbe pointed out that when demand is equivalent to supply, there will be no action is necessary but, on the opposite, action is needed. However, when action is mandatory, it make available the basis for recruitment and retention. In any case, if necessary, downsizing plans will be contemplated in consequence of the excess workers. The process is concluded with developmental activities, since the problem associated with surplus of workers and shortage of workers can be resolved if the mind-set of development is instilled in the human resource planning process and implementation. By the same token, Armstrong (2009) mentioned the human resource planning approaches as follows:

- Scenario planning - making broad assessments of future environmental factors and their likely impact on people requirements.

- Demand forecasting - estimate future needs for people and competences by reference to corporate and functional plans and forecasts of future activity levels.

- Supply forecasting - estimate the supply of people by reference to analyses of current resources and future availability, after allowing for wastage. The forecast will also take account of labour market trends relating to the availability of skills and to demographics. 
- Forecasting requirements - analyse the demand and supply forecasts to identify future deficits or surpluses with the help of models, where appropriate.

- Action planning - prepare plans to deal with forecast deficits through internal promotion, training or external recruitment. If necessary, plan for unavoidable downsizing so as to avoid any compulsory redundancies, if that is possible. Develop retention and flexibility strategies.

Armstrong observed that even though, the activities are distinctly stated, but are narrowly interconnected and often overlap. For instance, 'demand forecasts are approximations of future necessities, and these may be organized on the basis of expectations about the output of employees. However, the supply forecast has to reflect productivity trends and how they can intrude the supply of people.

\subsection{Impact Of Human Resource Planning On Organization's Performance}

Rogers and Wright, (1998) mentioned that organizational performance is one of the most generally and widely used reliant variables in organizational studies today, and yet, at the same time, it remains one of the most inaccurate and loosely-defined concepts. In the strategy literature, the focus of attention on this concept has been concerned almost entirely with financial measures of performance. Theoretically, organizational performance has been defined as 'the comparison of the value produced by a company with the value owners expected to receive from the company' (Alchian and Demsetz 1972). Richard et al. (2009) observed that the growing and strong competitiveness in the market has necessitated performance as the most essential subject for profit and non-profit organizations. It consist of three precise areas of firm result which comprises financial performance, product market performance and stockholder profit.

Therefore, organizational performance can be measured through financial strength and productivity, but then when we have to relate human resource planning with the organizational performance, at that moment we have to consider some of the other variables like efficiency and effectiveness, employee motivation, job satisfaction, trust on employees (Liu Y et al. (2007). Cho, et al. (2005 cited in Afzal et al. 2013) expressed that Human resource planning is surrounded by three basic level of practices that can increase the organizational performance such as:

1. To increase the knowledge, skills and abilities among employees.

2. To enhance their empowerment like giving them employment security and organize some participation programs for employees.

3. To give them motivation through both incentive means like giving them compensation and benefits, and also through internal promotion like promoting them with their job status.

As pointed out by Edwards and Pearce (1988) Human resource planning on the whole is essential for emerging, rapid-growth and high tech businesses. Matured business that are in need of new products, services, markets, acquisitions or divestitures must likewise plan to identify, attract or reallocate the talent necessary for revitalization and continued competition. In addition, in order to stay competitive, training and career development needs of employees should be satisfactory. Likewise, the following aspects should occupy a central role in businesses such as, the fulfillment of organizational demands, succession planning and organizational development strategies. According to Craft (1980), Human resource planning has possession of an important part in determining and insist on the physical characteristics of applicants, in order to handpick the best fit the organization looks for. Aslam et al (2013) also expanded that it is essential to correctly carry out human resource planning in order to prevent the potential problems and threats to the organization's competitive edge.

Furthermore, the prominence of swelling productivity has become one of the most serious goals in business. Thus; human resource planning is very crucial for reaching and the fulfillment 
of this productivity (Armstrong A. 1992). Therefore, there is a connection 'between human resource planning and employee productivity which position and significance has been mentioned by Ubeku (1975) through the identification of activities that can improve managerial effectiveness and consequently bring about employee productivity. According to Ubeku (1975) human resource planning is necessary for employee productivity as it helps in motivation, performance appraisal, and compensation management. It also make available sufficient time and place for seminar, workshop, training and development and other career development programs to the development of human resource for productivity. Moreover, human resource planning is important for productivity because, it makes consistent working environment.

According to Combs et al (2006; Guest, 2011) effectively managing organizational performance lead to speed performance attitude that can represent the sense that 'meeting every performance benchmark is essential at all times'. With this purpose in mind, Daft (2000) believed that in managing organizational performance, top managers through the suggestions of line managers, can constantly plan based on the available resources. As well as organize, human and other resources; over and above, 'coordinate certain undertakings and short-workings, and induce the attainment of strategic intent in order to satisfy the desires of all stakeholders'. In addition, individual and collective (team) performance management coordination play a vital role, as well. Moyo (2015) pointed out that through observation it is concluded that the practice of effective HRP in any particular organization will enhance the creation of competitive advantage in production of goods and market share, leading to high performance of that organization.

Acquaah (2004) perceived that HRM practices evolve organisational effectiveness and performance by attracting, identifying, and keeping employees with knowledge, skills, and abilities, and getting them to conduct themselves in the manner that will support the mission and aims of the organisation. In this manner, the usefulness of HRM practices can be determined by how it incorporates the suitable assertiveness and behaviour in employees. Moreover, to its implementation, Stanton and Nankervis (2011) further stated that organisational performance can be enhanced, mainly through increased productivity and employment leap, through ranging the whole employees' performance results with wide-ranging strategic business and HRM commitments. In this way, the management of particular employee's performance, and their combined contributions to whole impressiveness, has perhaps become the most important real HRM function in all organisations.

In addition, it is significant that a firm circumscribes HRM practices that create the finest utilization of its employees. This development has steered greater interest than before on the impact of HRM on organisational performance. And, series of studies have discovered that there is promising relationship between the unproven high-performance work practices and diverse dealings of company performance (Huselid 1995). Thus, Yslmaz \& Bulut (2015) opined that in the growing competitive world, human resource departments are expected to contribute to organisational performance. Therefore, a lot of organisations nowadays accept the fact that any achievement in the strategic management process may largely depend on the magnitude in which human resource function is contained within. More so, an increased in employees' involvement also requires an increased in training that employees can appreciate.

In his observation Mursi (2003), found out that there are significant and positive relationship between HR planning and organizational performance. In another study by Hiti (2000), HR planning have a positive relationship with organizational performance. In another study by Al-Qudah et al 2014) manpower planning has an effect on organizational performance and have a positive relationship between manpower planning and organizational performance. For 
the same reason therefore, training and development could influence organizational performance since, employees' skills, knowledge and abilities can be enhanced and be up to date (Subramaniam et al. 2011).

\section{Methodology}

The study reviewed the human resource planning and organizational performance through the use of secondary data from related books, journals and related materials on websites so as to find out how organizations use HRP tool for competitive advantage in the present global market.

\section{Discussion}

As competition heighten in the global market, human resource planning has gained a positive view from organizations in accepting employees as veritable assets in line with human resource management philosophy. Therefore, organisations nowadays need to have employees that possess the right skills that can be place in the right places and at the right time they will be needed in organizations. Since, human resource planning determines the right numerical strength of individuals that own these skills that are needed by organisations to meet the present and future business requirements. In order to fulfill this condition, HR planning ought to be part of any organization objective as; it warrants the organization to be positive in achieving all its objectives. Incredibly, many organizations have the propensity of overlooking the side of HR planning and more or less organizations are even not absolutely conscious of it. However, organizations that are regularly overlooking HR planning, take the risk of not surviving in the long run since; a proper HR planning can help organisations in dealing with a lot of issues in the appropriate way. Consequently, human resource planning is about critical human resource necessities, choice and interaction.

Moreover, the literature review discovered that the purpose of human resource planning in every single organization is to make sure that perfect use of human resource presently employed as well as, making provision for the future human resource needs vis-à-vis skills, quantities and ages. It is a way of ensuring that the organization at all times have the right number of people, with the correct level of skills to do the right activities at the right time for the accomplishment of organizational objectives. It is therefore, imperative for organizations to shape their objectives in line with what they expect to achieve with the aim of meeting their specific requirements as regards to the quantity and quality of employees they may need now and in the future.

Furthermore, HRP is playing a central role in apprehending the organization's objectives for instance, getting the right aptitude with the right skills, at the right time and for the right cost. HRP also have the ability to ascertain organizational requirements for skills and proficiencies which organizations can be utilized at present and in the future. More importantly HRP can use numerous approaches to settle up-to-date and anticipated workforce needs such as 'demographic analysis and retirement projections'. Based on HRP attributes, it is necessary for organizations to apply HRP process in order to have the right systems in place that can safeguard organizations to have the right jobs in place and contract the right people to do the right jobs right. HRP can also assist managers to bring together facts that can help them to make comprehensive decisions that can support their organizations to reach their goals. Nevertheless, there are challenges in human resource planning such as: matching current needs of organizations to that of their employees as well as those of the future. And, since organizations change more rapidly nowadays, in relation to the knowledge, skills, and behaviors wanted from their employees; this means that people working for organizations will now be required to constantly adjust to these new conditions. 
In addition, another significant factor of HR Planning is that it is vital in improving organizational productivity and efficiency as it gets the best human resource, utilize and develop them in the best way along with concentrating on corporate goals. Besides, HRP helps to reduce doubt, unnecessary labour cost and standardizes production. For these reasons, human resource planning is very critical for productivity.

\section{Conclusion}

The review found out that human resource planning is about critical human resource necessities, choice and interaction and its methods are differently expressed but barely interrelated and coincided on thoughts and drive. Therefore, the review discovered that there is positive as well as important relationship between HR planning and organizational performance.

\section{References}

Acquaah M. (2004), Human factor theory, organizational citizenship behaviors and human resources management practices: An integration of theoretical constructs and suggestions for measuring the human factor, Review of Human Factor Studies, Vol 10(1) 118-151.

Afzal F., Mahmood K., Sherazi S.M.R. Sajid M. \& Hassan M. (2013) Effect of Human Resource Planning on Organizational Performance of Telecom Sector, Information and Knowledge Management www.iiste.org ISSN 2224-5758 (Paper) ISSN 2224-896X (Online) Vol.3, No.2, 2013.

Akhigbe O. J, (2013) Human Resource Planning: A Key Factor in Ensuring the Effectiveness and Efficiency of Organization, Journal of Emerging Trends in Economics and Management Sciences (JETEMS) 4(4):388-396 C Scholar link Research Institute Journals, 2013 (ISSN: 2141-7024) jetems.scholarlinkresearch.org.

Alchian A. A., \& Demsetz H. (1972), Production, information costs, and economic organization. Source: The American Economic Review, Vol. 62, No. 5 (Dec., 1972), pp. 777-795

AL-Qudah M.K M. et al (2014) The Effect of Human Resources Planning and Training and Development on Organizational Performance in the Government Sector in Jordan' International Journal of Academic Research in Business and Social Sciences April 2014, Vol. 4, No. 4 ISSN: 2222-6990.

Al Wahshi A. S. (2016) Human resource planning practices in the Omani Public Sector: An exploratory study in the Ministry of Education in the Sultanate of Oman Edith Cowan University Research Online Theses: Doctorates and Masters 2016.

Armstrong Anona (1992) Management Skills and Performance Audit. First published: June 1992 https://doi.org/10.1177/103841119202900402. Asia pacific journal of Human resources.

Armstrong Michael (2009), A Handbook of Human Resource Management Practice $11^{\text {th }}$ Edition Kogan Page London and Philadelphia p486, 487

Aslam H. D., Aslam Mehmood, Ali N., Habib B and Jabeen M. (2013) Human Resource Planning Practice in Managing Human Resource: A Literature Review International Journal of Human Resource Studies ISSN 2162-3058 2013, Vol. 3, No. 1

Ayer, Lee. \& Reeves, Todd. (1995). Human resource strategies and firm performance: what do we know and where do we need to go? International Journal of Human Resource Management, Volume 6, 1995 - Issue 3.

Bello B. A. et al. (2017) Effective Human Resource Planning and Employee's Performance in the Oil and Gas Industry in Nigeria, JORIND 15(2) December, 2017. ISSN 1596-8303. www.transcampus.org/journal; www.ajol.info/journals/jorind 
Biles, George, E., \& Holmberg, Stevan, R. (2010), Strategic human resource planning, Glenn Ridge,

Brumbach, GB. (1988) some ideas, issues and predictions about performance management first Published December 1, 1988

Campbell J. P. (1999), The definition and measurement of performance in the new age. In D. R. Ilgen, \& E. D. Pulakos (Eds.), the changing nature of performance: Implications for staffing, motivation, and development (pp. 399-429). San Francisco: Jossey-Bass.

Cania, Luftim (2014), the Impact of Strategic Human Resource Management on Organizational Performance Economia. Jel Classification: L25, O15, P17 Seria Management Volume 17, Issue 2, 2014

Chan J. \& Burgess J. (2010), Human resource reporting and positioning in ten Hong Kong listed companies. International Employment Relations Review, 16(1), 1.

Choudhury, Enamul H. (2007), Workforce planning in small local governments. First Published September 1, 2007

Combs J., Liu Y., Hall A., \& Ketchen D. (2006) How much do high-performance work practices matter? A meta-analysis of their effects on organizational performance. Personnel Psychology, 59: 501.

Craft J. (1980), A critical perspective on human resource planning. Human Resource Planning, 3$197-211$

Daft R. L. (2000), Firm theory and design. South - Western College Publishing, Thompson learning, U.S.A.

DeCenzo D. A \& Robbins, S. P. (2019), Supervision today. Pearson New York, NY

Edwards G and Pearce E. (1988), 'Inevitable Forces for Change in America'.

Guest D. E. (2011), Human resource management and performance: Still searching for some answers. Human Resource Management Journal.

Hiti K. A. (2000), Human Resource Management: A strategic Entrance, Oman: Dar Hamid Library.

Huselid M.A. (1995), The Impact of Human Resource Management Practices on Turnover, Productivity, and Corporate Financial Performance, Academy of Management Journal Vol. 30 No3 635-872.

Janssens, M., \& Steyaert, C. (2009). HRM and Performance: A Plea for Reflexivity in HRM Studies. Journal of Management Studies 46(1):143-155.

Liu Y., Combs J. G., Ketchen Jnr D. J, \& Duane Ireland R. (2007) the value of human resource management for organizational performance Article in Business Horizons 50(6):503-511

Lunenburg, F.C. (2012) Human Resource Planning: Forecasting demand and supply. International

Journal of Management, Business, and Administration Volume 15, Number 1, 2012.

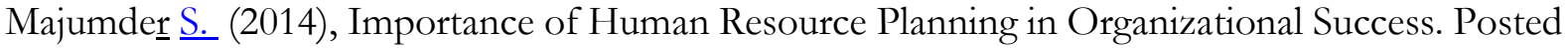

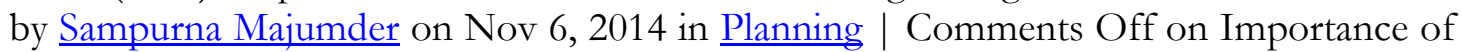
Human Resource Planning in Organizational Success. Retrieved from hrcsuite.com/human-resource-planning/ on the 15/12/18

Marchington M. and Wilkinson A. (1996) Core Personnel and Development. Retrieved from https://www.researchgate.net/publication/266395783 Core Personnel and Developm ent on the 16/09/2019

Meisinger S. (2007), Workforce planning anticipates change. HR Magazine, 52(1), 10.

Mills, D. (2013), Implementing strategy with the balanced scorecard: An introduction to the strategy-focused organization, DM Review.

Miner J. B, \& Crane D. P. (1995), Advances in the practice, theory, and research of strategic human resource management: To accompany Miner/Crane human resource management: the strategic perspective. New York: HarperCollins, (C1995. 
Moyo N. J. (2015) The Contribution of Human Resources Planning in Public Institutions Performance: A Case Study of Mlele District Council A Dissertation Submitted in Partial Fulfillment of the Requirements for the Degree of Master of Human Resource Management of the Open University of Tanzania 2015.

Mursi J. (2003), The strategic management of human resources: The entrance to achieve Competitive advantage to joining the twenty-first century. Alexandria: University House.

Nyamupachari, V. (n.d) Importance of Human Resources Planning in organisations. Retrieved from https://www.scribd.com/document/214012901/Hr-Planning-Vareta

Parker, B., \& Caine, D. (1996) Holonic modelling: human resource planning and two face of janus. International Journal of Manpower ISSN: 0143-7720 Publication date: 1 December 1996.

Randhawa, G. (2007) Human resource management. Atlantic Publishers \& Distributors (P) Ltd Publication Date: 2007 Binding: Softcover Book Condition: New. [Accessed 14/09/2019]

Reilly, P (1999) the Human Resource Planning Audit, Cambridge Strategy Publications, Cambridge.

Richard O.C. Simon T. \& Brut G. (2009), Measuring Organizational Performance: Towards Methodological Best Practice. Journal of Management Sciences, 76: 276323.

Rogers E. W. \& Wright P. M. (1998), Measuring organizational performance in strategic human resource management: Problems and prospects.

Santos A. Zhang A. Gonzalez M. \& Byde A. (2009), Workforce Planning and Scheduling for the HP IT Services Business Copyright 2009 Hewlett-Packard Development Company, L.P.

Stainer G.T. (2012), Introduction: from personnel management to human resource management, A critical Text, Thomson Learning. London.

Stannack P. (1996) Perspective on Employee Performance Management Research News, Publication date: 1 April 1996.

Stanton P. Nankervis A. (2011), linking strategic HRM, performance management and organizational effectiveness: perceptions of managers in Singapore Vol.17, 2011 - Issue 1.

Subramaniam C., Shamsudin F. M. \& Ibrahim H. (2011), Linking human resource practices and organisational performance: Evidence from small and medium organizations in Malaysia. DOI: 10.1756/pengurusan-2011-32-04.

Terry O. and Michael C.A. (2010), On the link between human capital and firm performance; A theoretical and empirical survey. FEP Working Paper no. 121, November p.1-38.

Ubeku Abel. K. (1975), Personnel Management in Nigeria. Benin City: Benin City, Nigeria: Ethiope Pub. Corp., 1975.

Ulferts G. (2009) Strategic Human Resource Planning in Academia American Journal of Business Education - October 2009 Vol. 2, No. 7, Retrieved from AIU library on the 21/01/19

Ulrich D. (1987), Strategic human resource planning: why and how? Human Resource Planning, Vol. 10, no. 1, 37-56.

Venkatraman N. \& Ramanujam V. (1986), Measurement of business performance in strategy research: A comparison of approaches. The Academy of Management Review

Vol. 11, No. 4 (Oct., 1986), pp. 801-814.

Walker J. W. (1990), Human resource planning, 1990 style. Human Resource Planning, Vol. 13, no. 4, 229-240.

Walker J.W. (2012), Human Resource Planning 1990's style Human Planning. Vol. 13 No. 4 PP229-40.

Werner S. Jackson S. E. \& Schuler R. S. (2012), Human Resource Management: South- Western Cengage Learning.

Wright P. M. \& McMahan G. C. (2011), Exploring human capital: putting 'human' back into strategic human resource management. Human Resource Management Journal

Yilmaz Ramazan \& Bulut Fatih M. (2015), the Effect of Human Resources Management on Organisational Performance Knuv 2015; 2(44): 5-13 